\title{
The effect of natural materials used as sediment remediation on phosphorus and nitrogen control in a mesocosm
}

\author{
Mengjuan Tang ${ }^{1}$, Qinghui Deng ${ }^{2,3}$, Xiaowen Li ${ }^{2,3}$, Xiuyun Cao ${ }^{2}$, Zhimin Zhang ${ }^{2}$, Yiyong Zhou², Qingye Sun ${ }^{1}$ \\ and Chunlei Song ${ }^{2^{*}}$ (D)
}

\begin{abstract}
Background: Achieving nitrogen $(\mathrm{N})$ and phosphorus $(\mathrm{P})$ control in sediment remediation projects by adding natural materials is receiving increasing attention. In this study, different natural materials, including iron-rich clay minerals, calcite, kaoline, sugarcane bagasse and Phragmites detritus, were applied to test their effects on N and P in a mesocosm experiment.
\end{abstract}

Results: Iron-rich clay minerals and Phragmites detritus had obvious advantages for P control; they resulted in almost undetectable levels of soluble reactive phosphorus (SRP) in the water column throughout the experiment. This finding can be explained by their strong $\mathrm{P}$ adsorption ability. The high level of available organic carbon in the sediment and water column after sugarcane bagasse addition provided enough electron donors for denitrification and dissimilatory nitrate reduction to ammonium (DNRA), which caused nitrate $\left(\mathrm{NO}_{3}{ }^{-}-\mathrm{N}\right)$ deficiency and ammonium $\left(\mathrm{NH}_{4}{ }^{+} \mathrm{N}\right)$ accumulation in the water column. Additionally, this resulted in anaerobic conditions, further fuelling the release of $P$ from iron-bound $P$ induced by anoxia. Thus, the amount of sugarcane bagasse applied should be considered carefully in order to balance denitrification and DNRA as well as P releases. Calcite and Phragmites detritus are recommended as remediation materials for $\mathrm{N}$ removal based on their significant promotion of denitrification and limitation of DNRA, which resulted in low $\mathrm{NO}_{3}{ }^{-}-\mathrm{N}$ and $\mathrm{NH}_{4}{ }^{+}$-N levels. These results can be explained by the shifts in the functional microbial community composition and abundance after the addition of natural materials.

Conclusions: Iron-rich clay minerals and Phragmites detritus are promising sediment remediation materials for $\mathrm{P}$ immobilization due to their strong $\mathrm{P}$ adsorption ability. Taken together, the selection of sediment remediation materials should consider the $\mathrm{N}$ and $\mathrm{P}$ coupling relationship, to prevent $\mathrm{NO}_{3}{ }^{-}-\mathrm{N}$ removal from causing $\mathrm{P}$ leaching or $\mathrm{NH}_{4}{ }^{+}-\mathrm{N}$ accumulation.

Keywords: Sediment remediation, Natural material, Organic carbon, Denitrification, DNRA

\section{Background}

Eutrophication, one of the most serious environmental problems, causes harmful algae to multiply and has led to the severe degeneration of the water quality in lakes

\footnotetext{
*Correspondence: clsong@ihb.ac.cn

2 State Key Laboratory of Freshwater Ecology and Biotechnology, Key Laboratory of Algal Biology, Institute of Hydrobiology, Chinese Academy of Sciences, Wuhan 430072, People's Republic of China

Full list of author information is available at the end of the article
}

worldwide [18, 39]. A prominent cause of eutrophication is high nutrient loadings, such as $\mathrm{N}$ and P loadings [46]. The biological toxicity and spectral characteristics of contamination in seriously polluted urban rivers are closely linked [5]. For example, in eutrophic water, microcystins produced from cyanobacteria can accumulate in fish tissues and then endanger organism and ecosystem health through food web transfer [40]. Furthermore, sediments that play a role in gathering pollutants can transport

\section{Springer Open}

(c) The Author(s) 2020. This article is licensed under a Creative Commons Attribution 4.0 International License, which permits use, sharing, adaptation, distribution and reproduction in any medium or format, as long as you give appropriate credit to the original author(s) and the source, provide a link to the Creative Commons licence, and indicate if changes were made. The images or other third party material in this article are included in the article's Creative Commons licence, unless indicated otherwise in a credit line to the material. If material is not included in the article's Creative Commons licence and your intended use is not permitted by statutory regulation or exceeds the permitted use, you will need to obtain permission directly from the copyright holder. To view a copy of this licence, visit http://creativeco mmons.org/licenses/by/4.0/. 
nutrients into the water column through biochemical and physical reactions [6]. Thus, when external $\mathrm{N}$ and $\mathrm{P}$ loadings have been controlled effectively, the release of internal nutrients dedicates to eutrophication increasingly [41].

The movement of endogenous nutrients is mainly caused by the relative environmental conditions [26]. For instance, several drivers of $\mathrm{P}$ release generally include $\mathrm{pH}$, dissolved oxygen, redox potential, temperature, flow rate and biological activity [24, 27]. $\mathrm{N}$ is usually released into water bodies as $\mathrm{NH}_{4}{ }^{-}-\mathrm{N}, \mathrm{NO}_{3}{ }^{-}-\mathrm{N}$ or nitrite $\left(\mathrm{NO}_{2}{ }^{-}-\mathrm{N}\right)$. The crucial factors that can result in the exchange of $\mathrm{N}$ at the sediment-water interface, mainly involve the capacity of sediments to retain nutrients (e.g., sediment accumulation rates), the conditions of the overlying water (e.g., dissolved oxygen, $\mathrm{pH}$, redox potential, temperature) and the biota (e.g., bioturbation, bioadvection or rates of microbial $\mathrm{N}$ transformation) [7, 30].

To date, numerous methods have been developed to control the release of endogenous nutrients. There are several possible methods of reducing internal $\mathrm{P}$ release in sediments, including artificial aeration; chemical applications, such as flocculation precipitation or adding $\mathrm{Fe}, \mathrm{Al}$ or Ca-based agents; and sediment capping $[10,16]$. The application of $\mathrm{CaO}_{2}$ effectively controlled the release of $\mathrm{N}$ and $\mathrm{P}$ from the sediment, and the concentrations of $\mathrm{N}$ and $\mathrm{P}$ in the overlying water were obviously reduced because of the increased microbiological action [44]. Illite is a useful agent for deactivating P for lake eutrophication control, and it has shown high efficiency (>130\%) as the capping material for both soluble reactive phosphorus (SRP) and total phosphorus (TP) [13]. Similarly, several efforts have been proposed to mitigate $\mathrm{N}$ releases. These strategies include capping [52], chemical injection [28] and microorganism fortification [45]. Among the capping techniques, the application of biochar resulted in the fluxes of $\mathrm{NH}_{4}{ }^{+}-\mathrm{N}, \mathrm{NO}_{3}{ }^{-}-\mathrm{N}$ and total nitrogen (TN) from sediments to water being significantly reduced or reversed [52]. In addition, the $\mathrm{TN}$ and $\mathrm{NH}_{4}{ }^{+}-\mathrm{N}$ removal efficiency increased obviously after the bioaugmentation of specialized bacteria [25].

However, even though these proposed methods had effects on the remediation of sediment in eutrophic lakes, they also revealed some drawbacks. For instance, several ecological risks are related to the use of chemical products. In addition, biological methods are susceptible to environmental factors [14]. Consequently, finding a material that is environmentally friendly, economic and efficient for the control of endogenous nutrient pollution in eutrophic lakes is a crucial issue.

In this study, five different natural materials, namely, iron-rich clay minerals, calcite, kaoline, sugarcane bagasse and Phragmites detritus, were added to eutrophic lake sediments to test their $\mathrm{N}$ and $\mathrm{P}$ control effects in a mesocosm experiment. Different forms of $\mathrm{N}$ and P, dissolved organic carbon (DOC) and chlorophyll $a(\mathrm{Chl} a)$ in the water samples were analyzed. The organic carbon composition; activities of leucine aminopeptidase (LAP), $\beta$-glucosidase (GLU) and alkaline phosphatase (AP); P fractionation and sorption; $\mathrm{N}$ transformation rates and the abundance and composition of the functional microbial communities in sediment samples were determined. The purposes of this study are to 1 ) test the effects of different natural materials on $\mathrm{N}$ and $\mathrm{P}$ levels; 2 ) describe the chemical and microbial mechanisms of $\mathrm{N}$ and $\mathrm{P}$ control by these materials; 3 ) highlight mutual effects on $\mathrm{N}$ and $\mathrm{P}$ control based on the relationship between $\mathrm{N}$ and $\mathrm{P}$; and 4) suggest promising natural materials for $\mathrm{N}$ and $\mathrm{P}$ control in sediment remediation.

\section{Materials and methods}

\section{Experimental design and sampling}

The 4-month experiment was conducted in 12 lab-scale columns made of PVC pipe. The inner diameter of the column was $300 \mathrm{~mm}$, and the height was $1200 \mathrm{~mm}$. The sediment and overlying water were collected from Lake Chaohu, which is seriously eutrophic. Sediment mixed with different natural materials was placed into each column to height of $50 \mathrm{~cm}$, followed by the overlying water, which was added slowly to avoid sediment suspension. The 12 columns were divided into six treatments in duplicate, namely, the control group (CT) and the ironrich clay mineral (IR), calcite (CA), Phragmites detritus $(\mathrm{PH})$, sugarcane bagasse $(\mathrm{SU})$ and kaoline $(\mathrm{KA})$ treatments. Iron-rich clay minerals, calcite and kaoline were chosen because of their high phosphorus sorption ability, while Phragmites detritus and sugarcane bagasse were used to provide organic carbon as an electron donor for denitrification.

Water samples from all treatments were collected and tested weekly, and equivalent amounts of water from Lake Chaohu were used to replenish the columns after sampling. The sediments were sampled by a Peterson grab sampler twice at the beginning of the experiment ( 9 March) and at the end (4 July). The water samples were processed on the collection day, and the sediments were stored at $4{ }^{\circ} \mathrm{C}$ in the dark for analysis within 1 week.

\section{Nutrient analysis}

The water samples were tested for $\mathrm{TN}$, dissolved total nitrogen (DTN), $\mathrm{NH}_{4}{ }^{+}-\mathrm{N}, \mathrm{NO}_{2}{ }^{-}-\mathrm{N}, \mathrm{NO}_{3}{ }^{-} \mathrm{N}, \mathrm{TP}$, dissolved total phosphorus (DTP), SRP, DOC and Chl $a$ contents. For the analyses of $\mathrm{N}$ and $\mathrm{P}$ species, water samples were filtered through $0.45-\mu \mathrm{m}$ cellulose acetate membranes for soluble nutrient preparation. All the methods followed national standards [2]. Dissolved 
organic nitrogen $(\mathrm{DON})$ was calculated as: $\mathrm{DON}=\mathrm{DTN}$ DIN, while DIN was calculated as the sum of $\mathrm{NH}_{4}{ }^{+} \mathrm{N}$, $\mathrm{NO}_{2}{ }^{-}-\mathrm{N}$ and $\mathrm{NO}_{3}{ }^{-}-\mathrm{N}$. Particulate nitrogen $(\mathrm{PN})$ was calculated as: $\mathrm{PN}=\mathrm{TN}-\mathrm{DTN}$. Dissolved organic phosphorus (DOP) was calculated as: DOP $=$ DTP-SRP. Particulate phosphorus $(\mathrm{PP})$ calculated as: $\mathrm{PP}=\mathrm{TP}-\mathrm{DTP}$. For the analysis of DOC, the water samples were filtered through GF/C filters (Whatman, USA) and measured by a Multi N/C 2100 TOC analyser. Chlorophyll $a(\mathrm{Chl} a$ ) was extracted from GF/C filters (Whatman, USA) with 90\% acetone and measured by the fluorometric method according to Yentsch and Menzel [47].

Total organic carbon (TOC) in the sediment was measured by loss-on-ignition in a muffle furnace [3]. Protein (PRT) analysis was conducted according to Hartree [17], and the values were expressed as bovine serum albumin (BSA) equivalents. The carbohydrate content $(\mathrm{CHO})$ was determined according to Gerchakov and Hatcher [11] and expressed as glucose equivalents. Lipids (LIPs) were extracted by direct elution with chloroform-methanol using the methods of Bligh and Dyer [4] and Marsh and Weinstein [29].

Sediment P fractionation was carried out according to Golterman [12]. The method groups sediment $\mathrm{P}$ into iron-bound $\mathrm{P}(\mathrm{Fe}(\mathrm{OOH}) \sim \mathrm{P})$, calcium-bound $\mathrm{P}$ $\left(\mathrm{CaCO}_{3} \sim \mathrm{P}\right)$, acid-soluble organic $\mathrm{P}$ (ASOP) and hot $\mathrm{NaOH}$-extractable organic $\mathrm{P}\left(\mathrm{P}_{\text {alk }}\right)$. The different forms of $P$ were sequentially extracted, and the SRP was detected.

The method for sediment $\mathrm{P}$ sorption was that of James et al. [22]. Five milliliters of sediment suspension was mixed with $10 \mathrm{~mL}$ of $0,0.1,0.2,1,2,5,8,10,15$, $20,25,30,40$, or $50 \mathrm{mg} / \mathrm{L} \mathrm{KH}_{2} \mathrm{PO}_{4}$ solution (containing $0.01 \mathrm{~mol} / \mathrm{L} \mathrm{KCl}$ ). The mixtures were mixed and shaken thoroughly for $24 \mathrm{~h}$ at $25{ }^{\circ} \mathrm{C}$. After centrifugation, the supernatant was filtered through a $0.45-\mu \mathrm{m}$ cellulose acetate membrane, and SRP was detected. The reduced phosphate from solution was considered adsorbed by sediment. The sorption parameters at equilibrium were calculated as [1]:

$$
S_{e}=\left(C_{0}-C_{e}\right) \mathrm{V} / \mathrm{m},
$$

where $\mathrm{S}_{\mathrm{e}}$ is the $\mathrm{P}$ sorption capacity at equilibrium (mg P/ $\mathrm{kg}), \mathrm{V}$ is the sample volume $(\mathrm{mL}), \mathrm{C}_{0}$ is the initial $\mathrm{P}$ concentration $(\mathrm{mg} \mathrm{P} / \mathrm{L}), \mathrm{C}_{\mathrm{e}}$ is the aqueous $\mathrm{P}$ concentration at equilibrium $(\mathrm{mg} \mathrm{P} / \mathrm{L})$, and $\mathrm{m}$ is the adsorbent amount $(\mathrm{kg})$.

The obtained data were fitted to the Langmuir adsorption isotherm equation [2] [38]:

$$
\frac{C_{e}}{S_{e}}=\frac{1}{S_{\max } K_{L}}+\frac{1}{S_{\max }} C_{e},
$$

where $S_{\max }$ is the maximum adsorbed concentration ( $\mathrm{mg}$ $\mathrm{P} / \mathrm{kg})$ and $K_{L}$ is the Langmuir equilibrium constant $(\mathrm{L} / \mathrm{mg}$ P).

All parameters for the nutrients mentioned above were measured in triplicate.

\section{Microbial activity analysis}

The activities of leucine aminopeptidase (LAP), $\beta$-glucosidase (GLU) and alkaline phosphatase (AP) were analyzed fluorometrically according to Hoppe [19], using the methylumbelliferone (MUF)-labeled substrates L-leucine-4-methylcoumarinylamide, MUF-beta-D-glucopyranoside and 4-methylumbelliferyl phosphate. In brief, slurries were made at a ratio of 1:10 by weight, and triplicates of 3-mL subsamples as the initial samples were added to $100 \mu \mathrm{M}$ of each specific fluorogenic substrate. The reaction was stopped immediately in an electrically heated $90{ }^{\circ} \mathrm{C}$ thermostatic water bath, while other triplicates of 3-mL slurries as final samples were incubated separately for $1 \mathrm{~h}$ with the same concentrations of each specific fluorogenic substrate. The fluorescence released by substrate hydrolysis was measured with a spectrofluorometer (Shanghai Sanco 960, Shanghai, China) as the increase between the initial time and $1 \mathrm{~h}$ of incubation.

The potential rates of denitrification and ANAMMOX were tested via the isotope-tracing method with a membrane inlet mass spectrometer (MIMS) [20, 35], and DNRA rates were determined by OX/MIMS [48]. The specific processes have been described by peer researchers [8]. Briefly, at a ratio of 1:7 by weight, the sediments and water were combined into a slurry, purged by helium for approximately $30 \mathrm{~min}$, and then transferred into 20 respective $12-\mathrm{mL}$ gas-tight vials (Labco Exetainers) under a helium atmosphere. To eliminate residual nitrite, nitrate, and oxygen, the vials were preincubated in a shaker at $150 \mathrm{rpm}$ for $24 \mathrm{~h}$. Then, ${ }^{15} \mathrm{NO}_{3}{ }^{-}$was added to the vials (final concentration approximately $100 \mu \mathrm{mol}$ ${ }^{15} \mathrm{~N} \mathrm{~L}^{-1}$ ) with a syringe, and $100 \mu \mathrm{L}$ of saturated $\mathrm{HgCl}_{2}$ was added to 10 of the replicates for preservation, 5 of which were DNRA initial samples. Another 5 vials were initial samples for ANAMMOX and denitrification. The remaining 10 samples were shaken $(200 \mathrm{rpm})$ and incubated for approximately $8 \mathrm{~h}$, and then the samples were preserved with $\mathrm{HgCl}_{2}$ as the final samples, half of which were tested for the dissolved nitrogen gas $\left({ }^{29} \mathrm{~N}_{2}\right.$ and $\left.{ }^{30} \mathrm{~N}_{2}\right)$ produced during the incubations for the ANAMMOX and denitrification rate calculation $[32,35]$. The other half were oxidized with hypobromite iodine solution to transfer the ${ }^{15} \mathrm{NH}_{4}{ }^{+}$produced by DNRA into nitrogen gas $\left({ }^{29} \mathrm{~N}_{2}\right.$ and $\left.{ }^{30} \mathrm{~N}_{2}\right)$, and the DNRA rates were calculated based on changes in the concentration of ${ }^{15} \mathrm{NH}_{4}{ }^{+}$during the incubations. 


\section{Metagenome DNA extract and sequencing}

To determine the abundance and composition of the functional microbial communities in the sediment samples, metagenomic analysis was conducted. Genomic DNA was extracted with commercial kits according to the manufacturer's instructions. DNA integrity and purity were monitored on $1 \%$ agarose gels. The DNA concentration and purity were measured using Qubit 2.0 (Thermo Fisher Scientific, Waltham, USA) and a Nanodrop One (Thermo Fisher Scientific, Waltham, USA) spectrophotometer at the same time. Sequencing libraries were generated using the NEB Next ${ }^{\circledR}$ Ultra $^{\mathrm{TM}}$ DNA Library Prep Kit for Illumina ${ }^{\circledR}$ (New England Biolabs, MA, USA) following the manufacturer's recommendations and index codes were added. The library quality was assessed on a Qubit 3.0 fluorometer (Life Technologies, Grand Island, NY) and Agilent 4200 (Agilent, Santa Clara, CA) system. Finally, the library was sequenced on the Illumina HiSeq X-ten platform.

\section{Statistical analysis}

In this study, triplicate samples were analyzed, and the data are presented as the mean \pm SD. The average value and standard deviation were analyzed in IBM SPSS Statistics 23. A statistical significance level within 0.05 was employed for all analyses. Nonlinear regression estimation for the model parameters was conducted in SigmaPlot 10.0 with the dynamic fit wizard function. The figures were drawn using OriginPro 9.0, and the concentrations of chemical parameters in water and sediments are displayed. Clustering based on the relative abundance of functional genes among the different treatments was performed using hierarchical clustering method and visualized through heatmaps using the Primer 5 and Adobe Illustrator CS6.

\section{Results}

\section{Nutrients in the water column}

The effects of the different natural eutrophic sediment remediation materials on nutrient levels in the water column and on algal growth and species were not exactly the same. There was a sharp increase in SRP concentration on the second sampling day (18 Mar, 9 days of incubation) in Treatment SU, which was maintained until 29 April (51 days of incubation). In the other treatments, SRP remained at a low level until the end of the experiment (3 June, 86 days of incubation), at which time the SRP began to increase in Treatments CT, KA and $\mathrm{CA}$, especially in Treatment $\mathrm{CT}$, indicating release of $P$ from the sediment. DOP and PP maintained low levels in almost all treatments except in Treatment SU, in which DOP and PP peaked on 8 April (30 days of incubation) and 1 April (23 days of incubation), respectively.
Additionally, in Treatment PH, the PP value was relatively high (Fig. 1).

$\mathrm{NH}_{4}{ }^{+}$- $\mathrm{N}$ showed a high value at the beginning of the experiment and then began to decrease and remained at a low level until the end of the experiment (107 days of incubation) in all treatments except Treatment SU, which always exhibited a high value of $\mathrm{NH}_{4}{ }^{+}-\mathrm{N}$ throughout the experiment. A low $\mathrm{NO}_{2}{ }^{-}-\mathrm{N}$ value was found in all treatments. There was a common pattern of a peak from 1 to 8 April (23-30 days of incubation) for the $\mathrm{NO}_{3}{ }^{-}-\mathrm{N}$ concentration in all treatments; the $\mathrm{NO}_{3}{ }^{-}-\mathrm{N}$ concentration was significantly lower $(P<0.01)$ in Treatments $\mathrm{PH}$ and SU than in the other treatments. DON and PN were not significantly different among the different treatments except in Treatment SU, which had peaks on 6 May (58 days of incubation) and 13 May (65 days of incubation), respectively (Fig. 2).

The DOC content in Treatment SU was an order of magnitude higher $(P<0.01)$ than that in the other treatments, showing a peak on 15 April (37 days of incubation). In almost all treatments, the Chl $a$ content was considerably low except in Treatment SU, which had a peak on 6 May (58 days of incubation). At the end of the experiment, relatively low $\mathrm{Chl} a$ content was found in Treatment IR (Fig. 3).

\section{Nutrient fractionation and sorption in sediment}

The addition of sugarcane bagasse and Phragmites detritus (Treatments $\mathrm{SU}$ and $\mathrm{PH}$ ) at the beginning of the experiment significantly stimulated the accumulation of TOC, PRT, CHO and LIP $(P<0.01)$, and the addition of kaoline (Treatment KA) at the beginning of the experiment increased the PRT content compared to the control. At the end of the experiment, the PRT, LIP and $\mathrm{CHO}$ in Treatment $\mathrm{PH}$ and the LIP in Treatment SU had increased significantly $(P<0.01)$, and $\mathrm{CHO}$ in Treatment SU had decreased significantly $(P<0.01)$ compared to those values at the beginning of the experiment. The carbon fractionation in most treatments did not change greatly during the whole experiment (Fig. 4).

The calcium- and iron-bound phosphor contents increased significantly $(P<0.01)$ after the addition of calcite and kaoline (Treatment CA and KA), respectively. In the treatments of $\mathrm{PH}$ and $\mathrm{SU}$, which had with organic carbon as the main component, obviously increased iron-bound $\mathrm{P}(P<0.01)$ was observed at the beginning of the experiment; iron-bound $\mathrm{P}$ declined considerably in Treatment SU at the end of the experiment (Fig. 5). In addition, compared to that in the control, relatively low values of the $\mathrm{P}$ sorption parameter $\mathrm{EPC}_{0}$ were found in Treatments $\mathrm{PH}$ and $\mathrm{SU}$, coupled with high $Q_{\max }$ values. Higher $\mathrm{EPC}_{0}$ values were recorded in Treatments IR and CA. The $Q_{\max }$ value increased significantly $(P<0.05)$ in all 


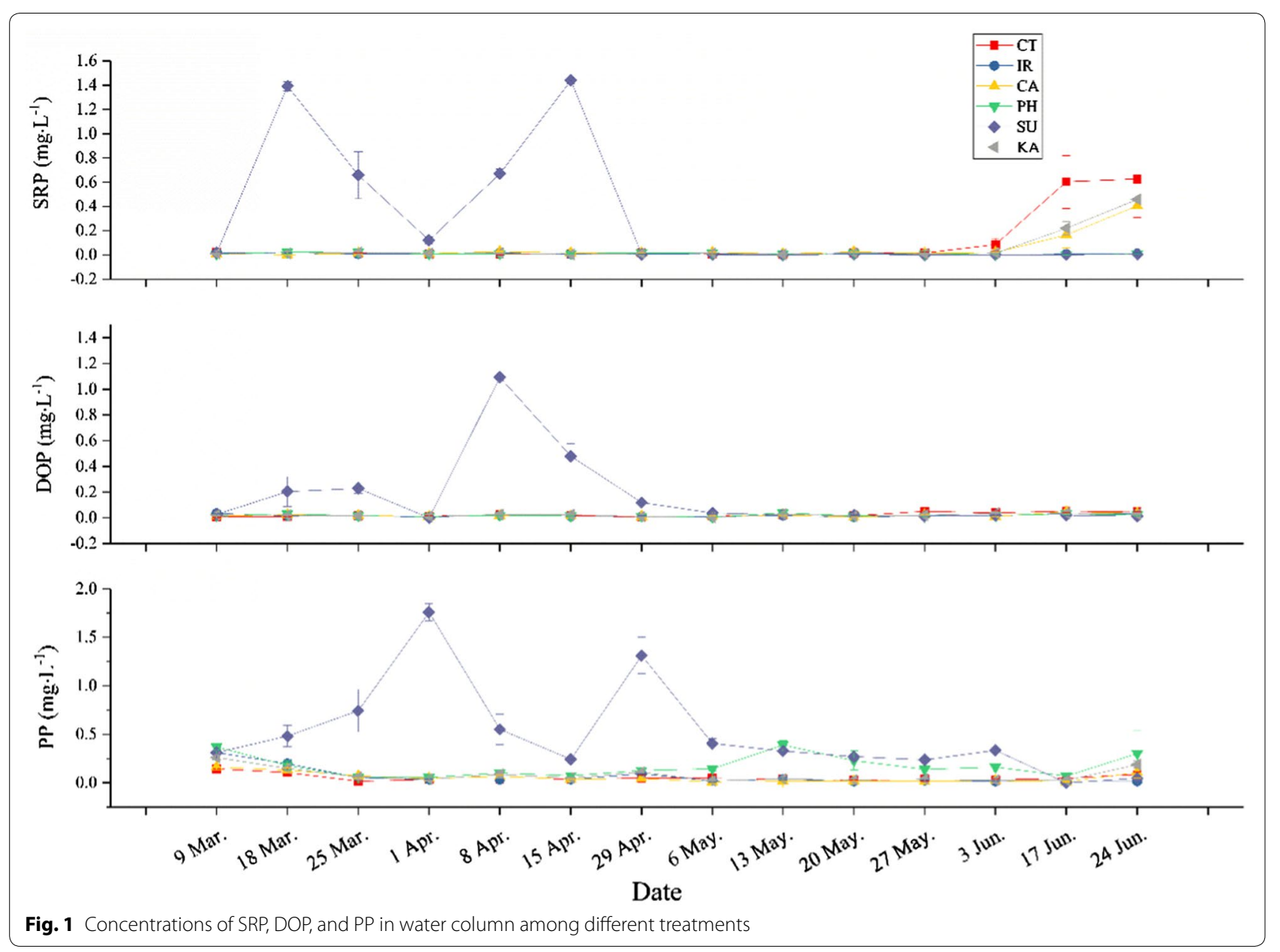

treatments from the beginning to the end of the experiment. $Q_{\max }$ had a significantly higher value $(P<0.01)$ in Treatment SU than in the other treatments (Fig. 6).

\section{Microbial activities, functional genes and microbial community composition in sediment}

The addition of sugarcane bagasse (Treatment SU) significantly inhibited the LAP, GLU and AP activities $(P<0.01)$ in sediments at the beginning of the experiment; the activity of the latter two enzymes increased sharply at the end of the experiment. The LAP activity did not vary greatly after the addition of natural materials except in Treatment SU and then dropped down to a very low level at the end of the experiment in all treatments. The addition of Phragmites detritus markedly stimulated GLU activity $(P<0.01)$ in Treatment $\mathrm{PH}$ throughout the experiment. AP activity was inhibited at the beginning of the experiment in all treatments (Fig. 7). The denitrification process dominated the $\mathrm{N}$ transformation processes. The denitrification rate was significantly promoted in Treatments CA, PH, SU and KA $(P<0.01)$ compared to that in the control. The difference was that in Treatments $\mathrm{PH}, \mathrm{SU}$ and KA, the DNRA rate was also greatly increased, while it was limited in Treatment CA. The ANAMMOX process was negligible in all treatments (Fig. 8).

The functional genes mediating $\mathrm{C}, \mathrm{N}$ and $\mathrm{P}$ cycling in all treatments showed completely different levels, with the highest and lowest levels in Treatment KA and SU, respectively. The number of functional genes mediating denitrification, DNRA, ammonification and phosphatase in Treatments IR, CA, PH and SU was significantly lower $(P<0.01)$ than that in Treatment CT. The number of functional genes mediating nitrification and carbon decomposition in Treatment CA was significantly higher than that in the other treatments except for Treatment KA $(P<0.01$, Fig. 9$)$.

The dominant taxa in the microbial community were completely different in all treatments. The dominant community included Cytophagales and Nitrosomonadales in the CT and IR treatments, respectively. In Treatment CA, Dehalococcoidia, Planctomycetales and 


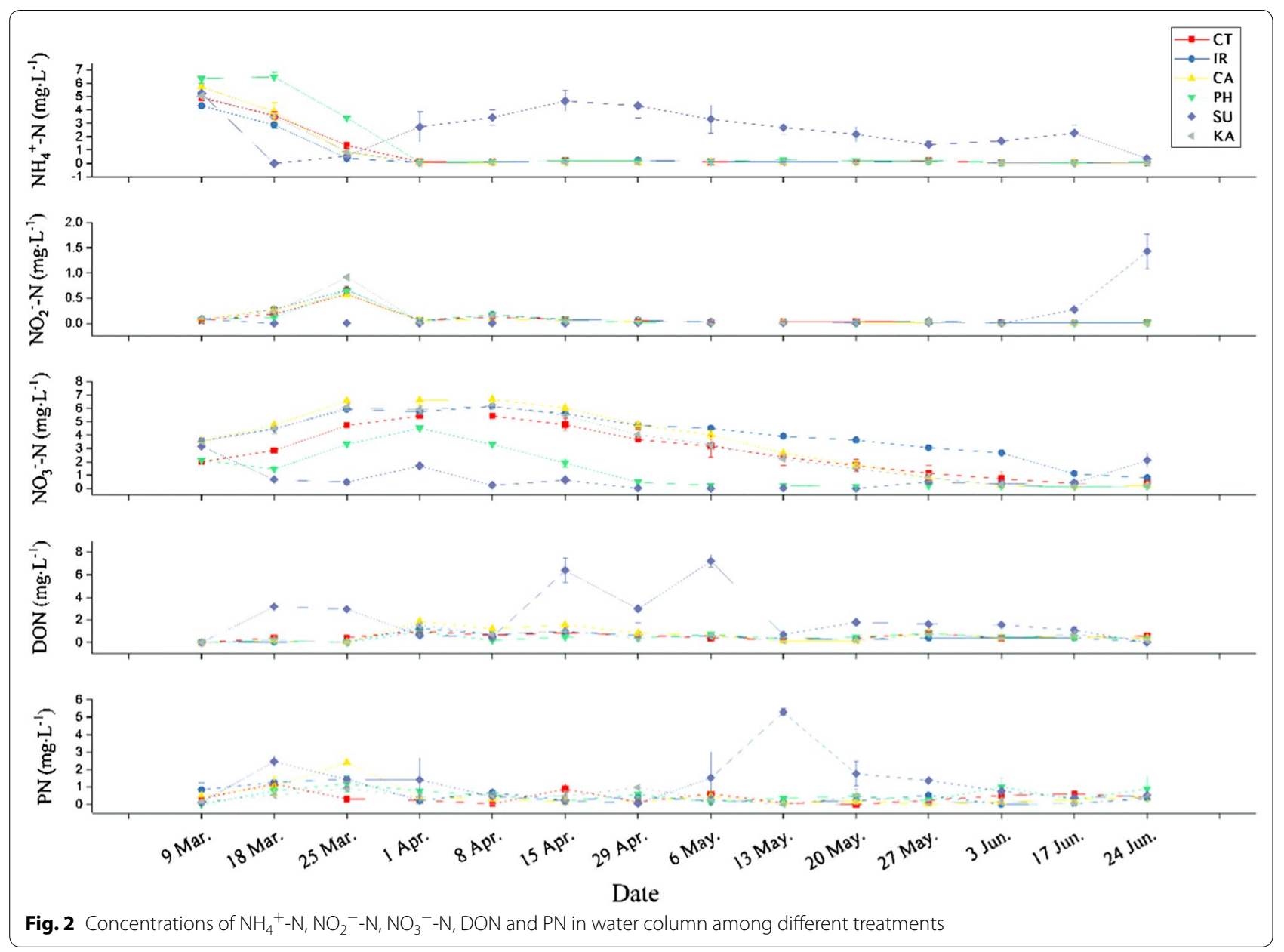

Nitrospirales dominated. In Treatment PH, the dominant community included Aeromonadales, Rhizobiales, Opitutales, Delta-proteobacteria, Syntrophobacterales and Chlorobiales. In Treatment KA, Proteobacteria, Chlamydiales and Bacillales dominated. Compared to that in the other treatments, the diversity of the microbial community composition in Treatment SU was more abundant, and the community was dominated by Methanomicrobiales, Methanocellales, Methanobacteriales, Methanosarcinales, Anaerolineales, Sulfuricurvum, Bacteroidales, Erysipelotrichales, Pseudomonadales, Clostridiales, Desulfovibrionales, Flavobacteriales and Desulfuromonadales (Fig. 10).

\section{Discussion}

\section{Effects of the addition of different natural materials on $\mathrm{P}$} control

At the beginning of the experiment, in Treatment $\mathrm{SU}$, all forms of phosphorus accumulated (Fig. 1), indicating that the addition of sugarcane bagasse caused P leaching in the initial phase. Sugarcane biomass increases significantly with P fertilizer application, suggesting that abundant phosphorus is stored inside sugarcane cells [1]. Additionally, the addition of sugarcane-derived biochar to sediment effectively stimulated phosphorus release [31]. Thus, the enzymatic hydrolysis of the organic $P$ in sugarcane bagasse is likely responsible for the P leaching to some extent, in accordance with the sharp increase in AP activity (Fig. 7). In addition, the significant increase in iron-bound P in Treatments PH and SU (Fig. 5) can be explained by the fact that the addition of sugarcane bagasse and Phragmites detritus resulted in partial inorganic P immobilization with ferric iron $[49,51]$. The immobilized iron-bound P in Treatment SU was subsequently released as shown by the decline in iron-bound $\mathrm{P}$ at the end of the experiment (Fig. 5). The most likely reason for this trend was the onset of anaerobic conditions, which facilitated the desorption of iron-bound $P$ [21]. Sustained hypoxia results in an initial decrease in sediment $\mathrm{P}$ content due to the dissolution of P-bearing iron oxyhydroxides, resulting in a pulse of phosphate to the overlying waters [34]. Furthermore, in Treatment 

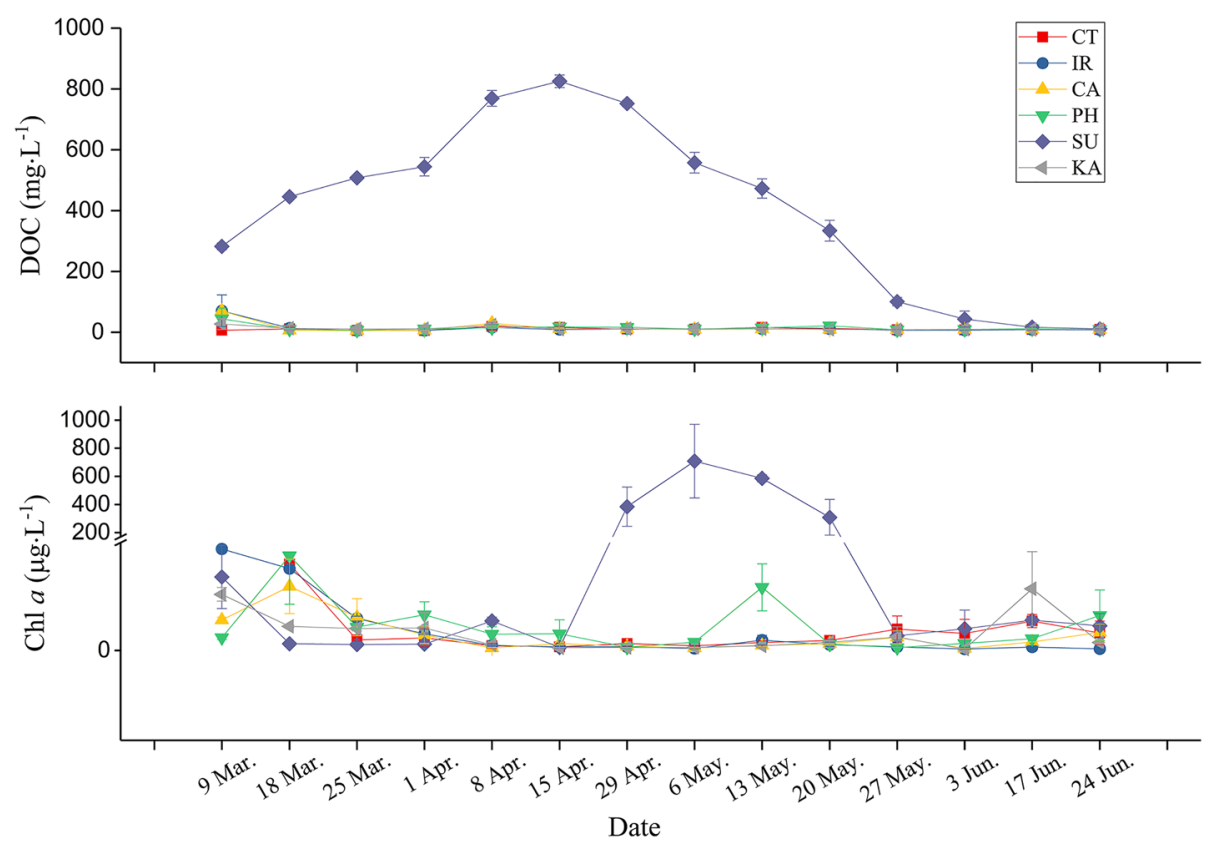

Fig. 3 Concentrations of DOC and Chl $a$ in water column among different treatments

$\mathrm{SU}$, a great deal of DOC was produced in the sugarcane bagasse decomposition process (Fig. 3), in which dissolved oxygen was consumed and anaerobic conditions developed. In summary, the addition of sugarcane bagasse caused $\mathrm{P}$ leaching, which can be attributed to the hydrolysis of the organic $\mathrm{P}$ in the plant cells and the release of iron-bound $\mathrm{P}$ due to serious anoxia.

However, it is worth noting that at the end of the experiment, all the P released in Treatment SU was re-immobilized (Fig. 1), which was associated with the strong $P$ sorption ability and potential of sugarcane bagasse, expressed by the relatively low $\mathrm{EPC}_{0}$ value and high $\mathrm{Q}_{\max }$ value (Fig. 6). In other words, even though the addition of sugarcane bagasse initially resulted in P leaching, it promoted $\mathrm{P}$ sorption, and the sugarcane bagasse adsorbed all released $\mathrm{P}$ in the end. At the end of the experiment, in Treatments CT, KA and CA, SRP was released gradually from the sediments (Fig. 1). This finding indicated that the addition of calcite and kaoline did not effectively inhibit $P$ release in the long term.

Phragmites can be considered an effective natural material for short-term $\mathrm{P}$ control in sediments due to its high sorption ability and low $\mathrm{P}$ leaching rate, although it might increase the iron-bound $\mathrm{P}$ content. Iron minerals maintained low $\mathrm{P}$ levels in the water column throughout the experiment, but their $\mathrm{P}$ sorption ability was weak. The release of the organic P fraction from Phragmites detritus is a longer-term process that may finally influence the balance of absorption and release of $\mathrm{P}$ in sediments. Hence, the effects of Phragmites detritus on $\mathrm{P}$ control require more studies in a long time series; the time course of this study (ca. 100 days) is not sufficient. Sugarcane bagasse should be applied prudently due to the initial P leaching that occurs, although it distinctly enhanced the $\mathrm{P}$ sorption ability and re-adsorb the released P. Calcite and kaoline could not maintain P fixation for a long period (Figs. 1, 5 and 6).

\section{Effects of the addition of different natural materials on $\mathrm{N}$ control}

The $\mathrm{NH}_{4}{ }^{+}-\mathrm{N}$ accumulation and $\mathrm{NO}_{3}{ }^{-}-\mathrm{N}$ deficiency in Treatment SU (Fig. 2) manifested weak nitrification and/or strong $\mathrm{NH}_{4}^{+}-\mathrm{N}$ production abilities. As mentioned above, in Treatment SU, the high DOC content and possibly anaerobic status (Fig. 3) indicated blocked nitrification. On the other hand, the increase in all carbon fractions after the addition of sugarcane bagasse, especially the increase in $\mathrm{CHO}$, which was rapidly consumed at the end of the experiment (Fig. 4), illustrated that sugarcane bagasse could provide abundant electron donors for $\mathrm{NO}_{3}{ }^{-}-\mathrm{N}$ reduction. Elevated DOC, including organic-rich sugars, has been detected in groundwater beneath irrigated sugarcane, which may be beneficial for denitrification [42]. Sugarcane straw increased the DOC by more than $50 \%$ in the topsoil layer and was positively correlated with $\mathrm{N}_{2} \mathrm{O}$ emissions [43]. Additionally, the organic carbon content of sugarcane bagasse facilitated denitrification in vertical flow 

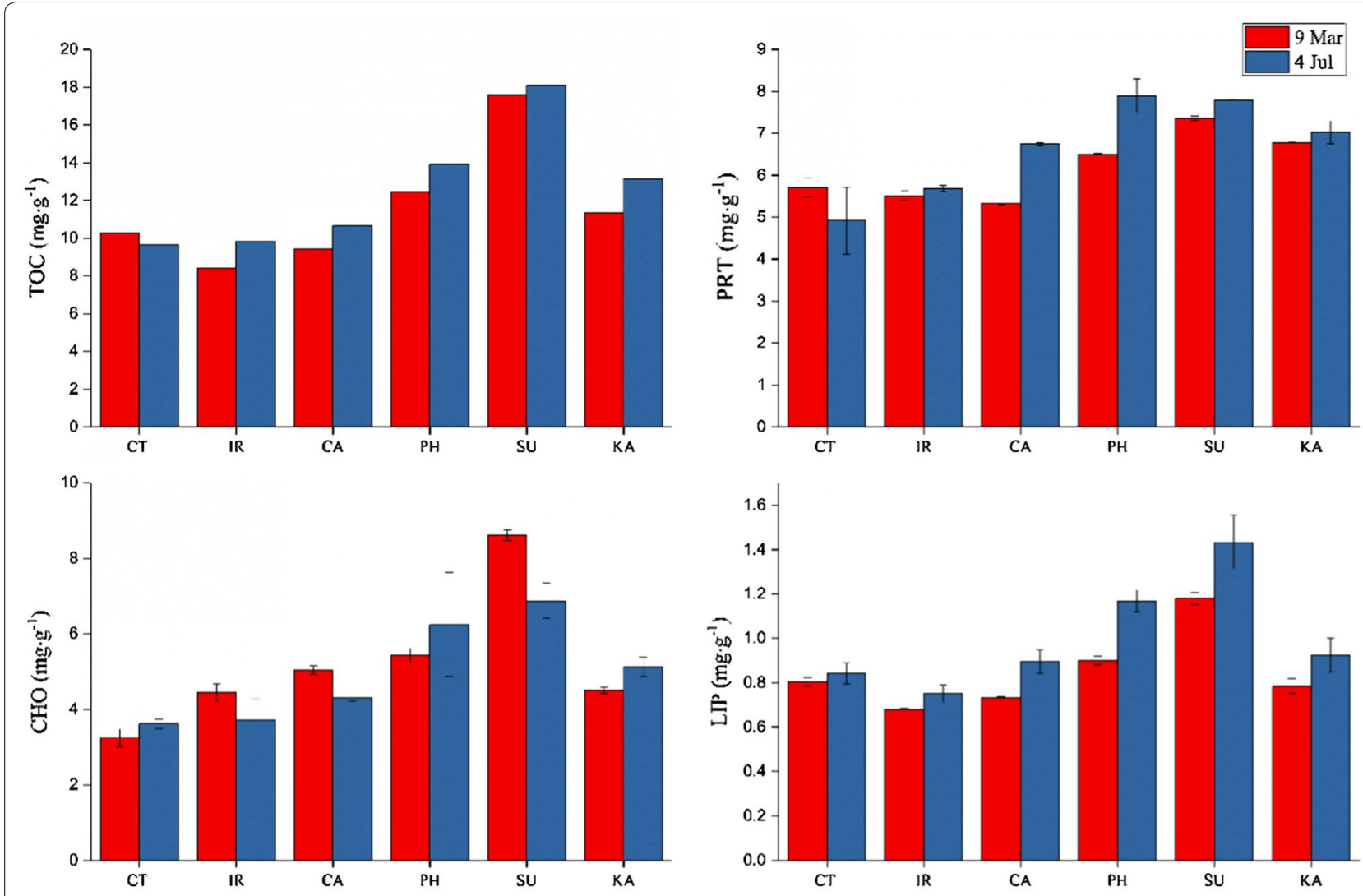

Treatment

Fig. 4 Comparison of TOC, PRT, CHO and LIP in sediments among different treatments

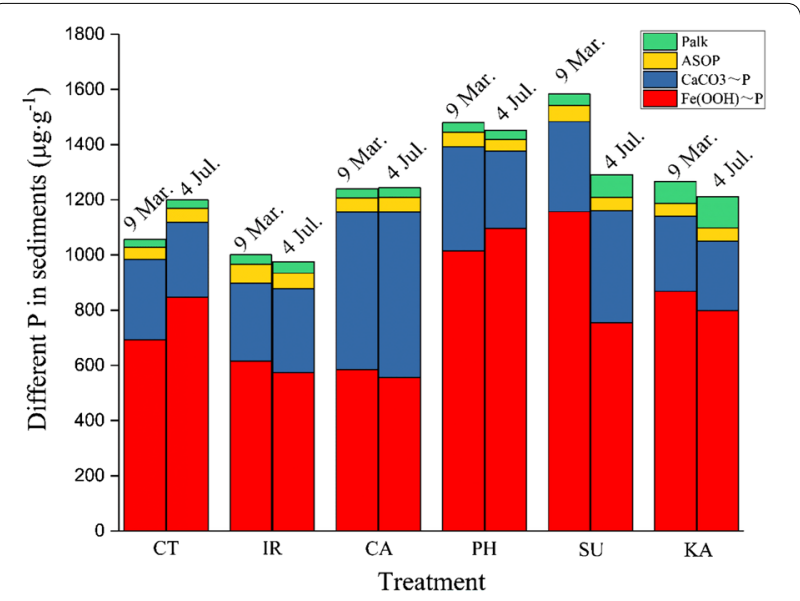

Fig. 5 Different $P$ in sediments among different treatments

wetlands [37]. This is the reason for the $\mathrm{NO}_{3}{ }^{-}$-N deficiency due to strong denitrification in Treatment SU. Furthermore, the significantly high denitrification and DNRA rates in Treatment SU (Fig. 8) supported the above conclusion. As a result, large amounts of $\mathrm{NH}_{4}{ }^{+}-\mathrm{N}$ and $\mathrm{N}_{2}$ were produced in Treatment SU (Fig. 2). In addition, the obviously low LAP activity, suggesting low ammonification in Treatment SU (Fig. 7), further illustrated that the DNRA process was primarily responsible for the $\mathrm{NH}_{4}{ }^{+}$-N accumulation. Organic carbon was the primary factor controlling the rates of dissimilatory nitrate reduction, accounting for $28.3 \%$ and $37.9 \%$ of the variance in the denitrification and DNRA rates, respectively [23]. High organic carbon and reducing conditions shifted $\mathrm{NO}_{3}{ }^{-}-\mathrm{N}$ reduction towards more pronounced DNRA [33]. Therefore, in Treatment SU, the high organic carbon level fuelled the DNRA process. In summary, weak nitrification, strong denitrification and DNRA after sugarcane bagasse addition jointly caused $\mathrm{NH}_{4}{ }^{+}-\mathrm{N}$ accumulation and $\mathrm{NO}_{3}{ }^{-}$-N deficiency. Coupled with $\mathrm{P}$ release, algal growth was greatly promoted in Treatment SU (Fig. 3).

Similarly, in Treatment $\mathrm{PH}$, all carbon fractions accumulated in sediments, especially PRT (Fig. 4). However, the lack of high DOC production (Fig. 3) indicated the low availability of the introduced organic carbon (Phragmites detritus) and the inactive organic carbon decomposition process, compared to that in 

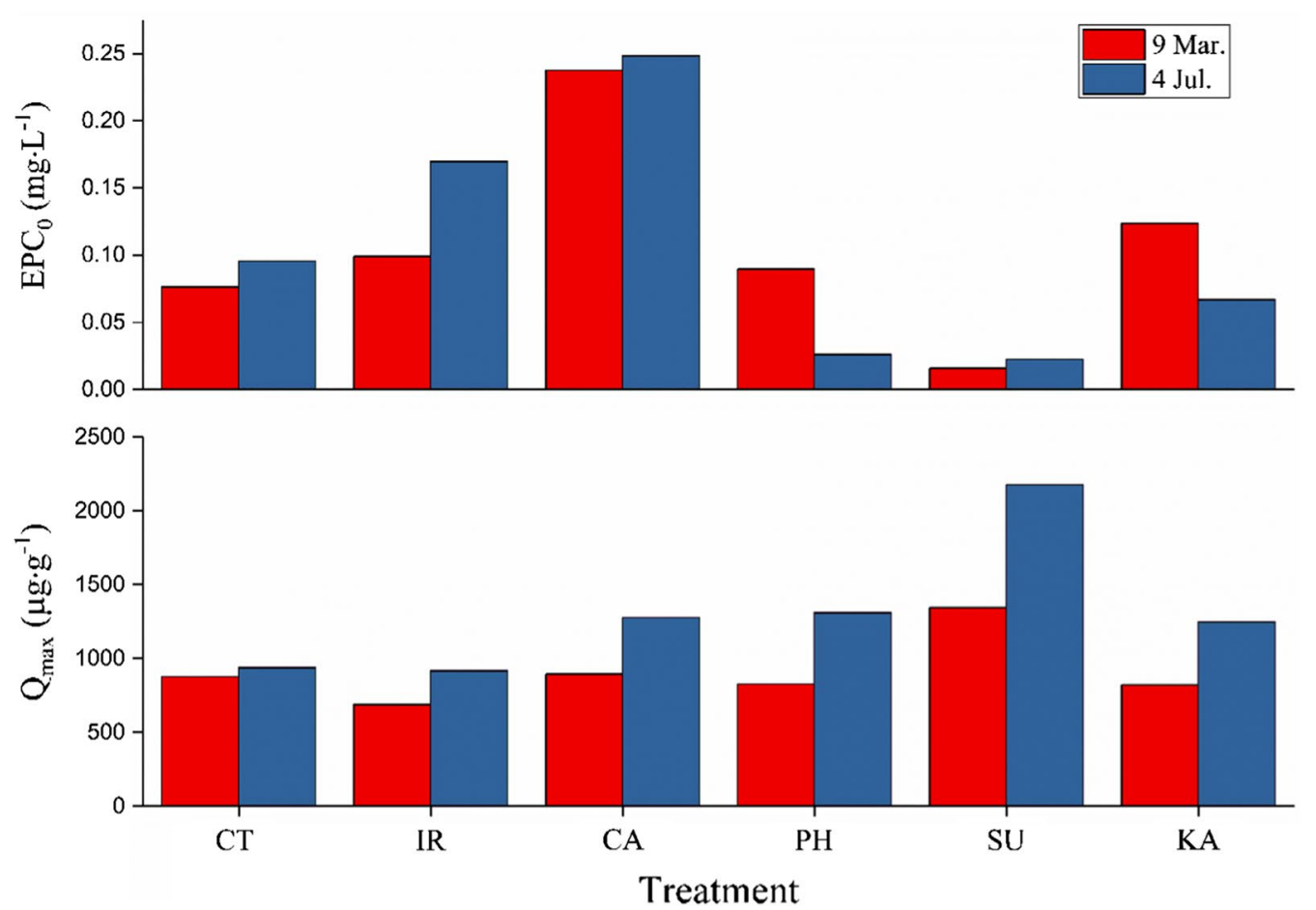

Fig. 6 The parameters of P sorption in sediments among different treatments

sugarcane bagasse. The low decomposition rate of Phragmites due to its component properties has been demonstrated [50], resulting in the low organic carbon availability and DOC leaching rate [9]. This suggests that the dissolved oxygen at the sediment-water interface should be sufficient and that organic carbon for electron donors should be sufficient but not excessive. Hence, the expected strong nitrification and denitrification as well as the weak DNRA, expressed as the denitrification and DNRA rates (Fig. 8), jointly led to the low $\mathrm{NH}_{4}{ }^{+}-\mathrm{N}$ and $\mathrm{NO}_{3}{ }^{-}-\mathrm{N}$ concentrations in Treatment PH (Fig. 2), even if a strong ammonification process had occurred (Fig. 7). Simply speaking, Phragmites detritus should be considered a promising natural material for introduction for $\mathrm{N}$ removal in sediment remediation projects.

The $\mathrm{NO}_{3}{ }^{-}-\mathrm{N}$ accumulation in Treatments CT, IR, $\mathrm{CA}$ and $\mathrm{KA}$ at the beginning of the experiment should be attributed to different mechanisms. In Treatments $\mathrm{CA}$ and $\mathrm{KA}$, at the beginning of the experiment, weak denitrification likely occurred due to the lack of electron donors. On the other hand, the high LAP activity indicated a strong ammonification process (Fig. 7), coupled with the predicted strong nitrification and weak denitrification; these factors jointly resulted in $\mathrm{NO}_{3}{ }^{-} \mathrm{N}$ accumulation at the beginning of the experiment.
However, during the experiment, organic detritus and some reductive metals inside calcite and kaoline were dissociated and served as electron donors for denitrification (Fig. 4); this may explain the high denitrification rate and low $\mathrm{NO}_{3}{ }^{-}-\mathrm{N}$ concentration at the end of the experiment (Figs. 2 and 8). There is evidence that electron donors exist on the surface of calcite [36]. During the formation of calcite, electron donors are needed for bacterial sulfate reduction [15]. The low denitrification rate (Fig. 8) due to electron donor deficiency (Fig. 4) in Treatment CT and IR directly resulted in the sustained maintenance of a high $\mathrm{NO}_{3}{ }^{-}-\mathrm{N}$ concentration (Fig. 2).

\section{Effects of the addition of different natural materials on microbial functional genes and community composition}

Treatment SU had the lowest levels of functional genes mediating $\mathrm{C}, \mathrm{N}$ and $\mathrm{P}$ cycling of all the treatments (Fig. 9), as well as a unique microbial community composition and rich microbial diversity (Fig. 10). These findings indicate that sugarcane bagasse addition shaped the microbial community and reduced the abundance of functional microorganisms, which responded with lower EEAs at the beginning of the experiment (Fig. 7). On the other hand, the increased denitrification and DNRA rates (Fig. 8) suggested that the excess organic carbon in Treatment SU (Figs. 3 and 4) resulted in a minority 


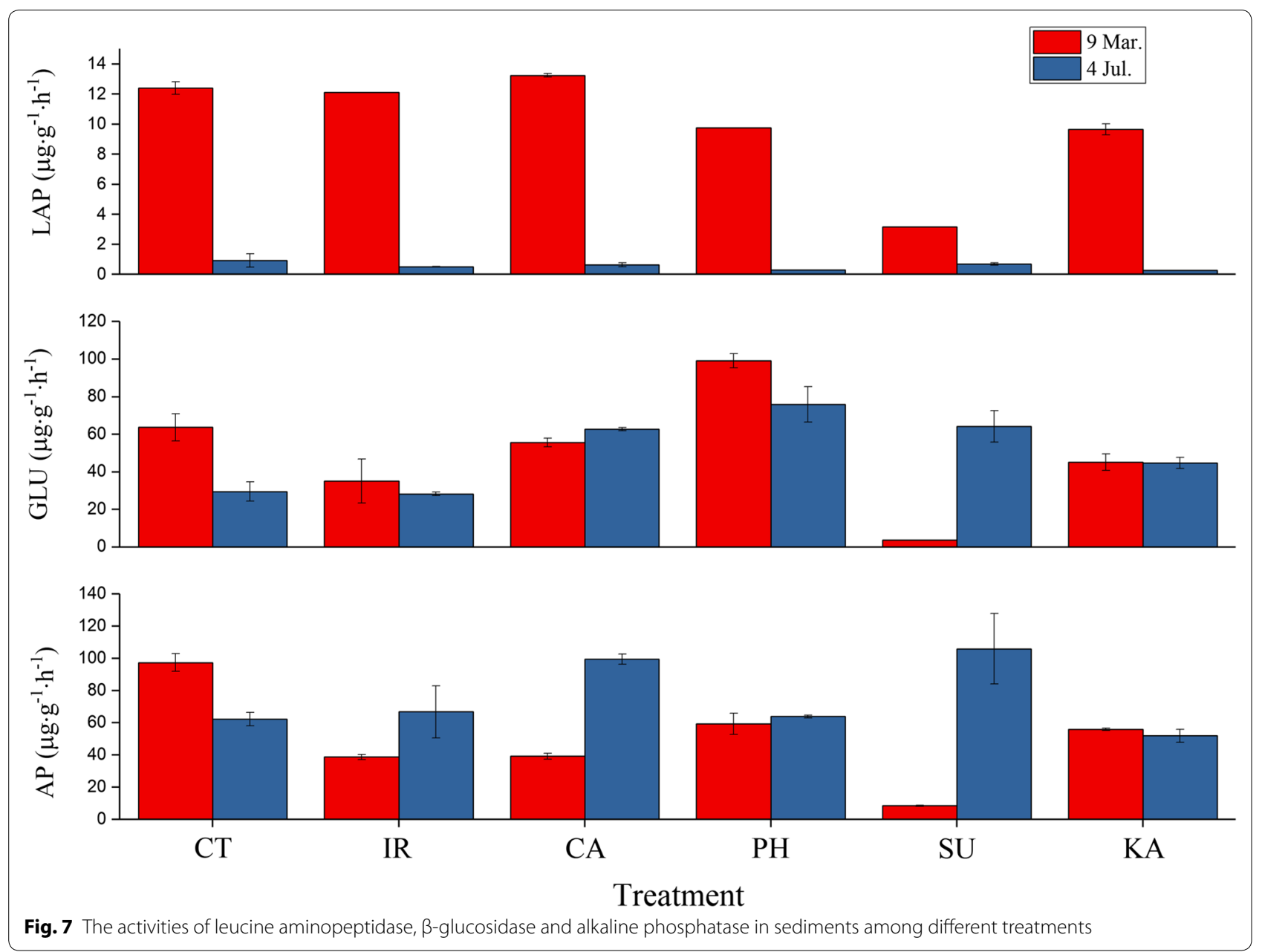

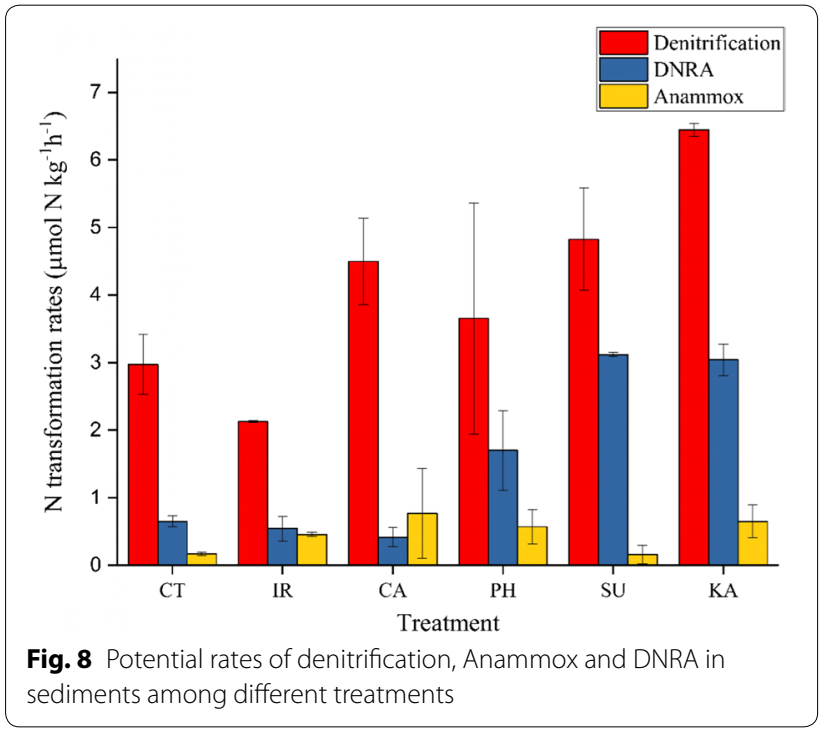

Fig. 8 Potential rates of denitrification, Anammox and DNRA in sediments among different treatments of functional microorganisms performing more functions (depending on the organic carbon). Additionally, in Treatment SU, the dominant microbial community species (Fig. 10) all grew in strictly anaerobic environments. Most of these microorganisms are capable of decomposing organic carbon and producing methane as well as reducing sulfate, which was consistent with the anaerobic status and abundance of organic carbon as well as the high denitrification and DNRA rates (Figs. 3, 4 and 8). Even though similar functions (organic carbon decomposition and methane production) were found in Treatments SU and $\mathrm{PH}$, the dominant microbial community compositions were different (Fig. 10), indicating the difference in organic carbon components during sugarcane and Phragmites detritus decomposition.

In Treatment KA, the high functional gene abundance and moderate denitrification and DNRA rates (Figs. 8 and 9) suggested that kaoline triggered functional promotion by greatly increasing the quantity of functional microorganisms. Additionally, the significantly high abundance of functional genes mediating nitrification and carbon 


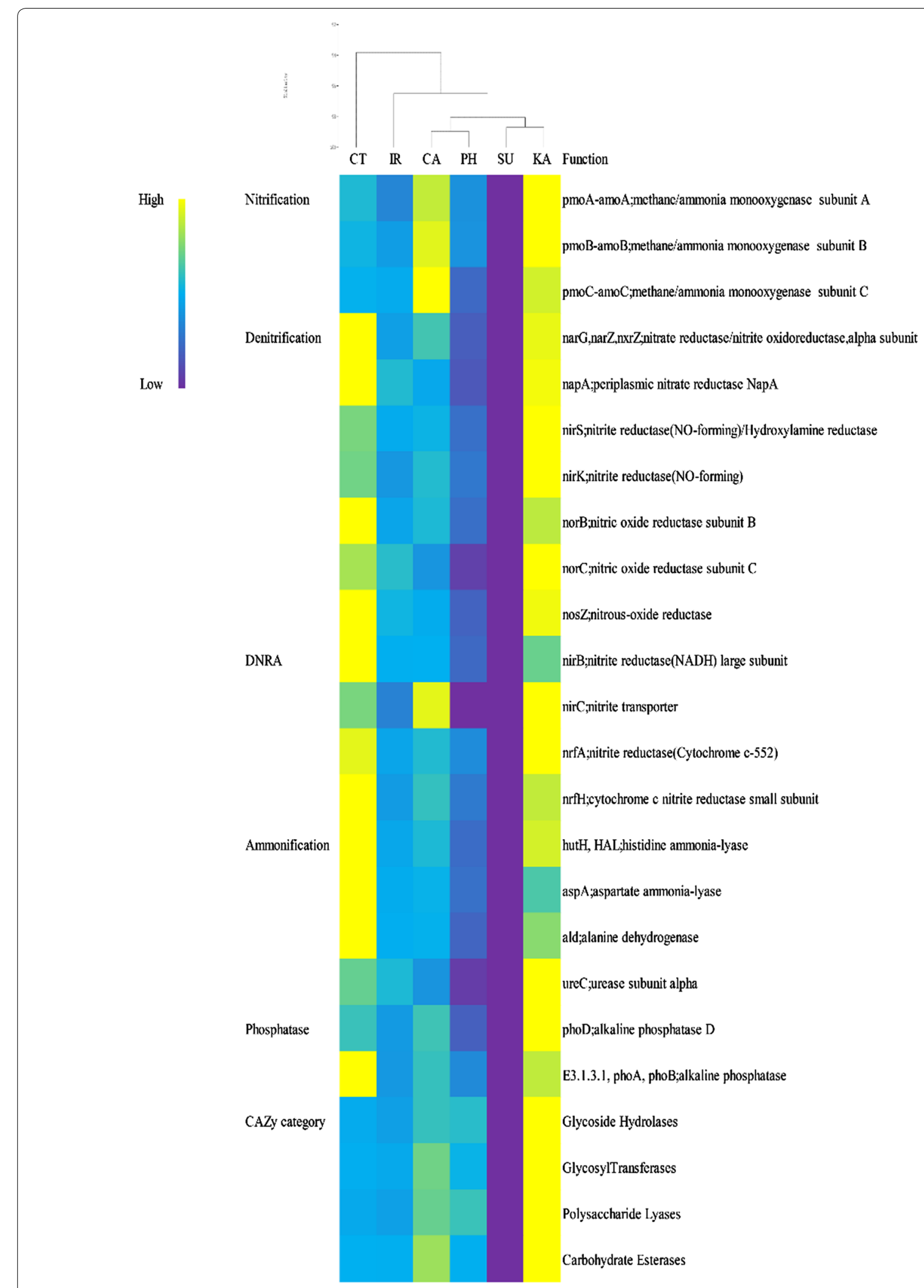

Fig. 9 Relative abundance of key functional genes mediating C, N and P cycling among different treatments 


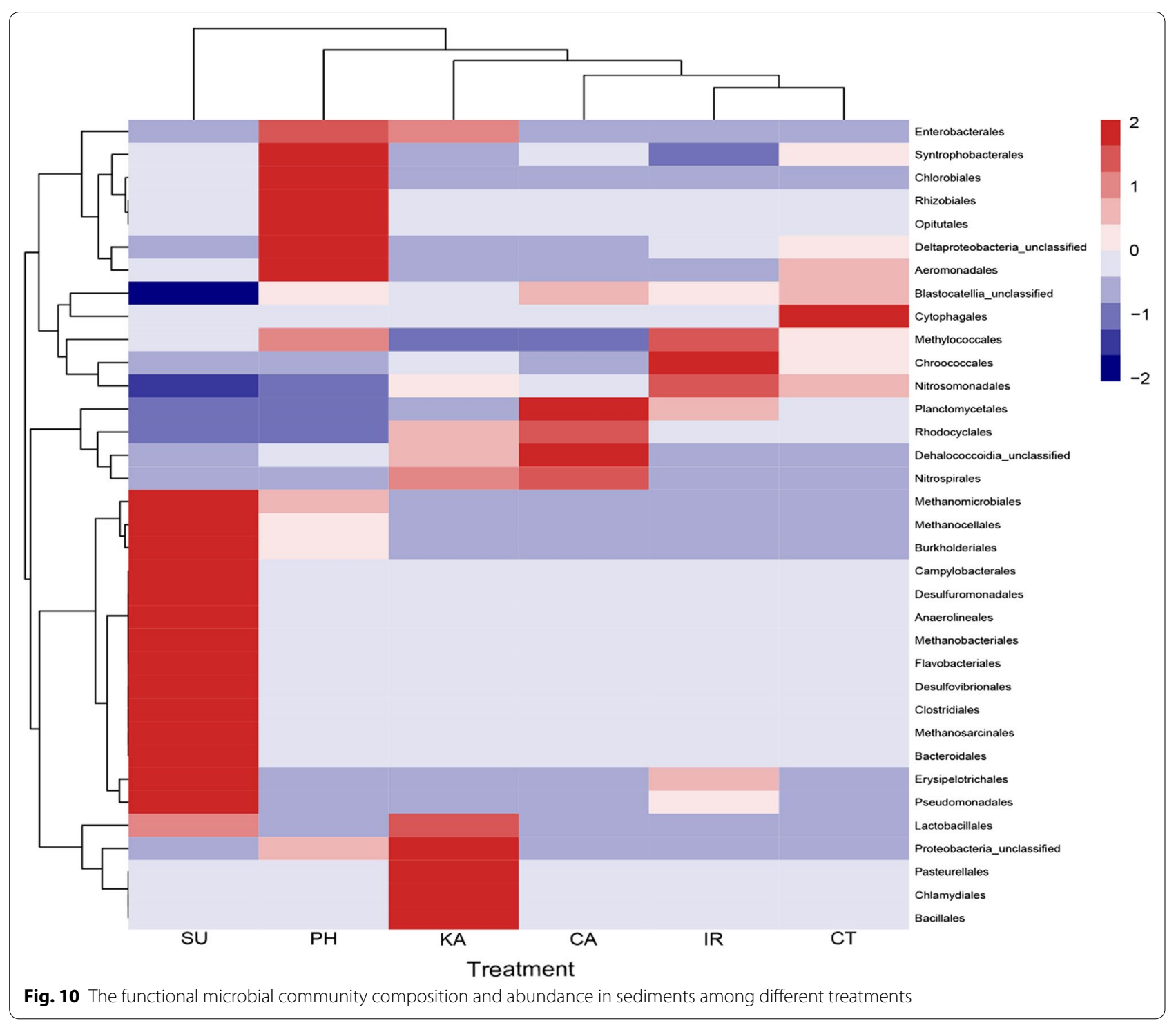

decomposition in Treatments CA and KA (Fig. 9) were corroborated by the similar dominant microbial community composition, such as Dehalogenimonas and Nitrospira (Fig. 10), which perform nitrification and organic matter decomposition. All these results illustrate that natural material addition both shapes community composition and changes the quantity of functional microorganisms, further determining ecological functions during $\mathrm{C}, \mathrm{N}$ and $\mathrm{P}$ cycling to a great extent.

\section{Conclusions}

The high level of available organic carbon in sediment and water after sugarcane bagasse addition provided a great deal of electron donors for denitrification and DNRA and also resulted in anaerobic conditions. The first consequence of this was $\mathrm{NO}_{3}{ }^{-}-\mathrm{N}$ deficiency and $\mathrm{NH}_{4}{ }^{+}$- $\mathrm{N}$ accumulation due to strong denitrification and DNRA as well as weak nitrification. The second consequence was a large amount of $\mathrm{P}$ leaching due to the release of iron-bound $\mathrm{P}$ induced by the anaerobic conditions. The third consequence was substantial algal growth due to the high $\mathrm{P}$ and $\mathrm{NH}_{4}{ }^{+}-\mathrm{N}$ levels. Thus, the amount of sugarcane bagasse applied for sediment remediation should be controlled in order to balance denitrification and DNRA and to reduce P leaching. Calcite and Phragmites detritus are recommended as remediation materials for $\mathrm{N}$ removal because their addition significantly accelerated the denitrification rate and restricted the DNRA rate, resulting in low $\mathrm{NO}_{3}{ }^{-}-\mathrm{N}$ and $\mathrm{NH}_{4}{ }^{+}-\mathrm{N}$. The results described above can 
be explained by the change in the functional microbial community composition and abundance after the addition of natural materials. Iron-rich clay minerals and Phragmites detritus should be regarded as promising sediment remediation materials for $\mathrm{P}$ immobilization due to their strong $\mathrm{P}$ adsorption ability. Taken together, the selection of sediment remediation materials for joint $\mathrm{N}$ and $\mathrm{P}$ control should consider the $\mathrm{N}$ and $\mathrm{P}$ coupling relationship, to prevent $\mathrm{NO}_{3}{ }^{-}-\mathrm{N}$ removal from causing $\mathrm{P}$ leaching or $\mathrm{NH}_{4}^{+}-\mathrm{N}$ accumulation.

\begin{abstract}
Abbreviations
SRP: Soluble reactive phosphorus; DNRA: Dissimilatory nitrate reduction to ammonium; $\mathrm{NO}_{3}{ }^{-} \mathrm{N}$ : Nitrate; $\mathrm{NH}_{4}{ }^{-}-\mathrm{N}$ : Ammonium; $\mathrm{NO}_{2}{ }^{-} \mathrm{-N}$ : Nitrite; TP Total phosphorus; TN: Total nitrogen; DOC: Dissolved organic carbon; $\mathrm{Chl}$ a: Chlorophyll $a$; LAP: Leucine aminopeptidase; GLU: $\beta$-Glucosidase; AP: Alkaline phosphatase; CT: Control; IR: Iron-rich clay mineral; CA: Calcite; PH: Phragmites detritus; SU: Sugarcane bagasse; KA: Kaoline; DTN: Dissolved total nitrogen; DTP: Dissolved total phosphorus; DON: Dissolved organic nitrogen; PN: Particulate nitrogen; DOP: Dissolved organic phosphorus; PP: Particulate phosphorus; TOC: Total organic carbon; PRT: Protein; BSA: Bovine serum albumin; $\mathrm{CHO}$ : Carbohydrate; LIP: Lipid; $\mathrm{CaCO}_{3} \sim$ P: Calcium-bound P; ASOP: Acid-soluble organic $\mathrm{P} ; \mathrm{P}_{\text {ak: }}$ : Hot $\mathrm{NaOH}$-extractable organic $\mathrm{P}$.
\end{abstract}

\section{Acknowledgements}

Not applicable.

\section{Authors' contributions}

$M T, Q D$ and $X L$ were involved in the experiments and manuscript writing. $X C$, $Z Z, Y Z$ and QS were responsible for the data analysis. CS contributed to the study design and manuscript correction. All authors read and approved the final manuscript.

\section{Funding}

This work was supported by the National Key Research \& Development Program of China (2016YFE0202100), the Strategic Priority Research Program of the Chinese Academy of Sciences (No. XDA23040403), the National Natural Science Foundation of China (41877381; 91951119), the Major Science and Technology Program for Water Pollution Control and Treatment (2017ZX07603), and State Key Laboratory of Freshwater Ecology and Biotechnology (2019FBZ01).

\section{Availability of data and materials}

The datasets obtained and analyzed during the current study are available from the corresponding author on reasonable request.

\section{Ethics approval and consent to participate}

Not applicable.

\section{Consent for publication}

Not applicable.

\section{Competing interests}

The authors declare that they have no competing interests.

\section{Author details}

${ }^{1}$ Anhui University, Hefei 230601, People's Republic of China. ${ }^{2}$ State Key Laboratory of Freshwater Ecology and Biotechnology, Key Laboratory of Algal Biology, Institute of Hydrobiology, Chinese Academy of Sciences, Wuhan 430072, People's Republic of China. ${ }^{3}$ University of Chinese Academy of Sciences, Beijing 100039, People's Republic of China.
}

Received: 28 February 2020 Accepted: 15 June 2020 Published online: 24 June 2020

\section{References}

1. Alvarado JS, McCray JM, Erickson JE, Sandhu HS, Bhadha JH (2019) Sugarcane biomass yield response to phosphorus fertilizer on four mineral soils as related to extractable soil phosphorus. Commun Soil Sci Plant Anal 50:2960-2970

2. APHA (2012) Standard methods for the examination of water and wastewater (22nd ed.). American Public Health Association (APHA), Washington, DC, USA

3. Auer RC, Yingst JY (1980) Relationships between microbial distributions and the anaerobic decomposition of organic matter in surface sediments of long Island Sound, USA. Mar Biol 56(1):29-42

4. Bligh EG, Dyer WJ (1959) A rapid method of total lipid extraction and purification. Can J Biochem Physiol 37(8):911-917

5. Chen Z, Zhu Z, Song J, Liao R, Wang Y, Luo X, Nie D, Lei Y, Shao Y, Yang W (2019) Linking biological toxicity and the spectral characteristics of contamination in seriously polluted urban rivers. Environ Sci Eur 31:84

6. Chon H, Ohandja D, Voulvoulis N (2012) The role of sediments as a source of metals in river catchments. Chemosphere 88:1250-1256

7. Cornwell JC, Owens MS (2011) Quantifying sediment nitrogen releases associated with estuarine dredging. Aquat Geochem 17(4-5):499-517

8. Deng F, Hou L, Liu M, Zheng Y, Yin G, Li X, Lin X, Chen F, Gao J, Jiang X (2015) Dissimilatory nitrate reduction processes and associated contribution to nitrogen removal in sediments of the yangtze estuary. J Geophys Res G Biogeosciences 120(8):1521-1531

9. Duke ST, Francoeur SN, Judd KE (2015) Effects ofphragmites australisinvasion on carbon dynamics in a freshwater marsh. Wetlands 35(2):311-321

10. Freeman Al, Surridge BWJ, Matthews M, Stewart M, Haygarth PM (2018) New approaches to enhance pollutant removal in artificially aerated wastewater treatment systems. Sci Total Environ 627:1182-1194

11. Gerchakov SM, Hatcher PG (1972) Improved technique for analysis of carbohydrates in sediment. Limnol Oceanogr 17(6):938-943

12. Golterman HL (1996) Fractionation of sediment phosphate with chelating compounds: a simplification, and comparison with other methods. Hydrobiologia 335(1):87-95

13. Gu BW, Hong SH, Lee CG, Park SJ (2019) The feasibility of using bentonite, illite, and zeolite as capping materials to stabilize nutrients and interrupt their release from contaminated lake sediments. Chemosphere 219:217-226

14. Guo C, Cui Y, Dong B, Luo Y, Liu F, Zhao S, Wu H (2017) Test study of the optimal design for hydraulic performance and treatment performance of free water surface flow constructed wetland. Bioresour Technol 238:461-471

15. Han X, Schultz L, Zhang W, Zhu J, Meng F, Geesey GG (2016) Mineral formation during bacterial sulfate reduction in the presence of different electron donors and carbon sources. Chem Geol 435:49-59

16. Hansen J, Reitzel K, Jensen HS, Andersen FØ (2003) Effects of aluminum, iron, oxygen and nitrate additions on phosphorus release from the sediment of a Danish softwater lake. Hydrobiologia 492(1):139-149

17. Hartree EF (1972) Determination of protein: a modification of the Lowry method that gives a linear photometric response. Anal Biochem 48(2):422-427

18. Heisler J, Glibert P, Burkholder J, Anderson D, Cochlan W, Dennison W, Gobler C, Dortch Q, Heil C, Humphries E, Lewitus A, Magnien R, Marshall H, Sellner K, Stockwell D, Stoecker D, Suddleson M (2008) Eutrophication and harmful algal blooms: a scientific consensus. Harmful Algae 8(1):3-13

19. Hoppe HG (1983) Significance of exoenzymatic activities in the ecology of brackish water: measurements by means of methylumbelliferyl-substrates. Mar Ecol Prog Ser 11:299-308

20. Hou L, Liu M, Carini SA, Gardner WS (2012) Transformation and fate of nitrate near the sediment-water interface of Copano Bay. Cont Shelf Res 35:86-94

21. Hupfer M, Lewandowski J (2008) Oxygen controls the phosphorus release from lake sediments-a long-lasting paradigm in limnology. Int Rev Hydrobiol 93:415-432

22. James BR, Rabenhorst MC, Frigon GA (1992) Phosphorus sorption by peat and sand amended with iron-oxides or steel wool. Water Environ Res 64:699-705

23. Jiang X, Gao G, Zhang L, Tang X, Shao K, Hu Y (2019) Denitrification and dissimilatory nitrate reduction to ammonium in freshwater lakes of the Eastern Plain, China: influences of organic carbon and algal bloom. Sci Total Environ 710:136303 
24. Jiang X, Jin X, Yao Y, Li L, Wu F (2008) Effects of biological activity, light, temperature and oxygen on phosphorus release processes at the sediment and water interface of Taihu Lake, China. Water Res 42(8-9):2251-2259

25. Jiao Y, Zhao Q, Jin W, Hao X, You S (2011) Bioaugmentation of a biological contact oxidation ditch with indigenous nitrifying bacteria for in situ remediation of nitrogen-rich stream water. Bioresour Technol 102(2):990-995

26. Lee HW, Lee YS, Kim J, Lim KJ, Choi JH (2019) Contribution of Internal Nutrients Loading on the Water Quality of a Reservoir. Water 11(7):1409

27. Li H, Liu L, Li M, Zhang X (2013) Effects of pH, temperature, dissolved oxygen, and flow rate on phosphorus release processes at the sediment and water interface in storm sewer. J Anal Methods Chem 2013:1-7

28. Liu T, Yuan J, Dong W, Wu H, Wang H (2014) Effects on inorganic nitrogen compounds release of contaminated sediment treatment with in situ calcium nitrate injection. Environ Sci Pollut Res 22(2):1250-1260

29. Marsh JB, Weinstein DB (1966) Simple charring method for determination of lipids. J Lipid Res 7(4):574-576

30. Medina HL, Marín JC, Gutiérrez E, Morales J (2003) Nitrogen mobility at the sediment-water interface of Lake Maracaibo, Venezuela. Water Air Soil Pollut 145:341-357

31. Motaghian $H$, Hosseinpur A, Safian M (2019) The effects of sugarcanederived biochar on phosphorus release characteristics in a calcareous soil. J Soil Sci Plant Nutr 20(1):66-74

32. Nielsen LP (1992) Denitrification in sediment determined from nitrogen isotope pairing. FEMS Microbiol Lett 86(4):357-362

33. Nizzoli D, Carraro E, Nigro V, Viaroli P (2010) Effect of organic enrichment and thermal regime on denitrification and dissimilatory nitrate reduction to ammonium (DNRA) in hypolimnetic sediments of two lowland lakes. Water Res 44:2715-2724

34. Reed DC, Slomp CP, Gustafsson BG (2011) Sedimentary phosphorus dynamics and the evolution of bottom-water hypoxia: a coupled benthic-pelagic model of a coastal system. Limnol Oceanogr 56(3):1075-1092

35. Risgaard-Petersen N, Nielsen LP, Rysgaard S, Dalsgaard T, Meyer RL (2003) Application of the isotope pairing technique in sediments where anammox and denitrification coexist. Limnol Oceanogr Methods 1:63-73

36. Ryazantseva MV, Bunin IZ (2015) Modifying acid-base surface properties of calcite, fluorite and scheelite under electromagnetic pulse treatment. J Min Sci 51(5):1016-1020

37. Saeed T, Sun G (2013) A lab-scale study of constructed wetlands with sugarcane bagasse and sand media for the treatment of textile wastewater. Bioresour Technol 128:438-447

38. Sakadevan K, Bavor HJ (1998) Phosphate adsorption characteristics of soils, slags and zeolite to be used as substrates in constructed wetland systems. Water Res 32(2):393-399

39. Schindler DW, Carpenter SR, Chapra SC, Hecky RE, Orihel DM (2016) Reducing Phosphorus to Curb Lake Eutrophication is a Success. Environ Sci Technol 50(17):8923-8929
40. Schmidt JR, Shaskus M, Estenik JF, Oesch C, Khidekel R, Boyer GL (2013) Variations in the microcystin content of different fish species collected from a eutrophic lake. Toxins 5:992-1009

41. Song K, Adams CJ, Burgin AJ (2017) Relative importance of external and internal phosphorus loadings on affecting lake water quality in agricultural landscapes. Ecol Eng 108:482-488

42. Thayalakumaran T, Lenahan MJ, Bristow KL (2015) Dissolved organic carbon in groundwater overlain by irrigated sugarcane. Groundwater 53(4):525-530

43. Vargas VP, Soares JR, Oliveira BG, Lourenço KS, Martins AA, Del Grosso SJ, Carmo JB, Cantarella H (2019) Sugarcane straw, soil temperature, and nitrification inhibitor impact $\mathrm{n} 20$ emissions from $\mathrm{n}$ fertilizer. Bioenergy Res 12(4):801-812

44. Wang Y, Wang WH, Yan FL, Ding Z, Feng LL, Zhao JC (2019) Effects and mechanisms of calcium peroxide on purification of severely eutrophic water. Sci Total Environ 650:2796-2806

45. Wu Q, Hu Y, Li S, Peng S, Zhao H (2016) Microbial mechanisms of using enhanced ecological floating beds for eutrophic water improvement. Bioresour Technol 211:451-456

46. Wu Q, Zhang R, Huang S, Zhang H (2008) Effects of bacteria on nitrogen and phosphorus release from river sediment. J Environ Sci 20(4):404-412

47. Yentsch CS, Menzel DW (1963) A method for the determination of phytoplankton chlorophyll and phaeophytin by fluorescence. Deep-Sea Res 10:221-231

48. Yin G, Hou L, Liu M, Liu Z, Gardner WS (2014) A novel membrane inlet mass spectrometer method to measure ${ }^{15} \mathrm{NH}_{4}^{+}$for isotopeenrichment experiments in aquatic ecosystems. Environ Sci Technol 48(16):9555-9562

49. Yu JH, Zhong JC, Chen QW, Huang W, Hu LM, Zhang YL, Fan CX (2018) An investigation of the effects of capping on internal phosphorus release from sediments under rooted macrophytes (Phragmites australis) revegetation. Environ Sci Pollut Res 25:24682-24694

50. Zhang L, Zhang YJ, Zou JW, Siemann E (2014) Decomposition of Phragmites australis litter retarded by invasive Solidago canadensis in mixtures: an antagonistic non-additive effect. Sci Rep 4:5488

51. Zhang WL, Zeng CS, Tong C, Zhai SJ, Lin X, Gao DZ (2015) Spatial distribution of phosphorus speciation in marsh sediments along a hydrologic gradient in a subtropical estuarine wetland, china. Estuar Coast Shelf Sci 154:30-38

52. Zhu $Y$, Tang W, Jin $X$, Shan B (2019) Using biochar capping to reduce nitrogen release from sediments in eutrophic lakes. Sci Total Environ 646:93-104

\section{Publisher's Note}

Springer Nature remains neutral with regard to jurisdictional claims in published maps and institutional affiliations.

\section{Submit your manuscript to a SpringerOpen ${ }^{\circ}$ journal and benefit from:}

- Convenient online submission

- Rigorous peer review

- Open access: articles freely available online

- High visibility within the field

Retaining the copyright to your article

Submit your next manuscript at springeropen.com 